\title{
Retinol and Alpha-Tocopherol Levels Among Hemodialysis Patients.
}

\author{
Awatif M. Abd El Maksoud*, Asmaa M. Abd Allah*, Waleed Massoud**, \\ Mervat A. Ismail*. \\ *Clinical Nutrition Department, National Nutrition Institute. \\ **Nephrology Department ,Ahmed Maher Teaching Hospital.
}

\begin{abstract}
Plasma retinol, alpha tocopherol, total cholesterol and triglycerides were measured in 40 patients aged 27-65 years, under regular hemodialysis (HD) for 1.8-13 years at Ahmed Maher teaching Hospital and in 28 healthy age and sex matched control. Predialysis and postdialysis measurements were also, done for a subset of 13 hemodialytic patients.

Among hemodialytic patients ,all values ( Plasma retinol ,alpha- tocopherol, total cholesterol and triglycerides )were significantly higher $(\mathrm{p}<0.05)$ with respect to healthy control .The ratio of retinol to total cholesterol was significantly higher, while alpha-tocopherol to total cholesterol ratio was insignificant .In almost all hemodialytic patients, plasma retinol was at toxic level (> $100 \mathrm{ug} / \mathrm{dl})$ except for one patient .

On the other hand ,alpha-tocopherol level in hemodialytic patients was ranged between deficiency $(<650 \mathrm{ug} / \mathrm{dl})$ in about $6(15 \%)$ of them, marginal level $(650-860 \mathrm{ug} / \mathrm{dl})$ at $3(8 \%)$ , while $9(23 \%)$ had normal level (860-1080ug/ dl) and the rest $22(54 \%)$ were in the optimum level (> $1080 \mathrm{ug} / \mathrm{dl})$. Comparing predialysis and postdialysis measurements, the hemodialytic patients showed non significant difference concerning retinol level, while alpha tocopherol was significantly decreased in postdialytic state .In conclusion; further studies are needed to answer, if hemodialytic patients are at risk for symptomatic vitamin A toxicity? Even with normal or low plasma vitamin E, it is needed as an antioxidant accessory therapy in hemodialytic patients.
\end{abstract}

Keywords: hemodialysis , retinol , alpha-tocopherol, triglycerides total cholesterol .

\section{Introduction}

Contributions of the kidney to vitamin A metabolism involve Retinol Binding Protein (RBP) metabolism, hepatic release of retinol and retinoic acid synthesis ( Chazot and Kopple,1997 ).Chronic renal failure patients, have elevated plasma concentrations of total vitamin A and RBPbound vitamin A. Elevated vitamin A is considered to be due to increased plasma $\mathrm{RBP}$, and have no clinical significance as long as the $\mathrm{RBP} / \mathrm{vit} \mathrm{A}$ ratio is normal ( Mydlik ,1991).

Chronic renal failure patients, who had no clinical features of vitamin A toxicity, have increased liver and skin vitamin A content. In the absence of increased serum prealbumin,an excess of vitamin A /RBP complex would easily bind to tissues with RBP receptors, causing toxic effects. In contrast, features of vitamin A toxicity in a skin examination of hemodialysis (HD) patients was not found although, they had elevated serum levels of RBP and retinol (Chazot and Kopple,2004).

Vitamin $\mathrm{E}$ is the most important defense against peroxidation of unsaturated lipids in cells and of plasma lipoproteins. The normal concentrations of vitamin $\mathrm{E}$ are inadequate to cover the need for protection in HD patients ( Usberti ,et al. 2002 ). In HD patients there was a decrease in concentration of red blood cell (RBC) tocopherol and there was marked decrease in lipid peroxidation in patients treated with 
alpha tocopheryl acetate (Pastor, et al.1993; Ongajooth, et al. 1996 ; Cristol, et al. 1997).This may be due to the oxidative stress or a defect in the high density lipoprotein(HDL) - mediated transfer of tocopherol from plasma to the RBC membrane ( Chazot and Kopple , 2004) .

The aim of this study was to evaluate plasma concentration of retinol and alphatocopherol in hemodialytic patients and their lipid pattern. Also,to detect the effect of hemodialysis on these parameters.

\section{Subjects and methods}

Forty stable hemodialytic patients ,24 (60\%) males and $16(40 \%)$ females were recruited from dialysis unit of Ahmed Maher teaching hospital, Cairo, Egypt. Patients were aged $49.5 \pm 11.3$ years with duration of HD for $4.5 \pm 2.4$ years (mean \pm SD) and were adequately dialysed with a mean $\mathrm{Kt} / \mathrm{V}$ of $1.12 \pm 0.23$ according to the DOQI guidelines (2002). End stage renal disease (ESRD) was due to, hypertensive nephropathy (16) patients (pts), diabetic nephropathy (8)pts, pyelonephritis (4)pts, renal stones (4)pts, polycystic kidney (2)pts, hyperparathyroidism (1) pt , and to unknown causes in five. All patients were on bicarbonate - hemophan dialyzers (modified cellulose). Twenty eight persons who were age and sex matched healthy control were also, recruited for the study. Informed consent were obtained from all people under the study.

Fasting (12 hours) venous blood samples were collected, plasma was separated by centrifugation at $3000 \mathrm{rpm}$ for 15 min. Plasma was used for determination of retinol and alpha- tocopherol using high pressure liquid chromatography (HPLC) according to Bieri et al. (1979). Also, total cholesterol (Allain, et al. 1974) and triglycerides (Wahlefeld, 1974) were determined using kits provided from biomerieux, France .Retinol and alphatocopherol were chosen out of the fat soluble vitamins ADEK, vitamin D was excluded due to complicated interactions and medications with renal failure (Jacobson, et al.1995).Vitamin K was also excluded to avoid variations in levels of its measurements due to the prevalence of hepatic diseases, cirrhosis and bilharsiasis among Egyptian hemodialysis patients (Afifi, 2003).

\section{Data handling and Statistical analysis}

The collected data were computerized and analyzed statistically through SPSSunder windows version 11. Excel computer program was used to tabulate the results. Qualitative variables were expressed as percentages. Quantitative variables from normal distribution were expressed as mean \pm S.E. Independent $t$ - test , and one -way analysis of variance (ANOVA) with the least significant differences (LSD) were used. The difference was considered signifycant at $\mathrm{p}$-value $<0.05$ levels (Armitage, 1971) .

\section{Results}

Plasma retinol level was markedly greater among HD patients than healthy control, it's level was about (8 fold) higher in HD patients compared to healthy persons $[465.27 \pm 26.72 \mu \mathrm{g} / \mathrm{dl}$ versus 61.14 $\pm 3.48 \mu \mathrm{g} / \mathrm{dl}, \mathrm{p} \leq 0.000]$.

As it's ratio to cholesterol was significantly higher in HD patients than control $[2.65 \pm 0.19$ versus $0.397 \pm 0.02, \mathrm{p} \leq$ $0.000]$ table (2).

Also, plasma alpha tocopherol was significantly higher among HD patients compared to healthy control [1323.04 \pm $150.32 \mu \mathrm{g} / \mathrm{dl}$ versus $891.24 \pm 36.21 \mu \mathrm{g} / \mathrm{dl}, \mathrm{p}$ $\leq 0.008$ ], while there was no significant difference regarding alpha tocopherol cholesterol ratio between HD patients and healthy control $[6.62 \pm 0.55$ versus $5.8 \pm$ $0.27, \mathrm{p}=0.19$ ] table $(2)$.

As regards lipid pattern ,both triglycerides (TG) and total cholesterol (Tch) were significantly elevated in HD patients compared with control group . For TG $[187.56 \pm 23.25 \mathrm{mg} / \mathrm{dl}$ versus $105.58 \pm$ $9.3 \mathrm{mg} / \mathrm{dl}, \mathrm{p} \leq 0.002]$. While cholesterol level was $[204.98 \pm 13.02 \mathrm{mg} / \mathrm{dl}$ versus $166.63 \pm 6.7 \mathrm{mg} / \mathrm{dl}, \mathrm{p}<0.05$ ] table (2).

There was no statistically significant difference between gender and all values 
(retinal, alpha tocopherols, total cholesterol, triglycerides). Also, there was no correlations between the primary cause of renal failure, age of the patients or the duration of dialysis and all measured values.

We also, studied the effect of HD on plasma level of retinol, alpha tocopherol ,lipid pattern and their ratios for subgroup of 13 patients table (3). The results showed significant decrease in alpha tocopherol level in post dialysis condition compared to pre dialysis one $[1284.23 \pm 245.18 \mu \mathrm{g} / \mathrm{dl}$ versus $1348.12 \pm 243.08 \mu \mathrm{g} / \mathrm{dl}, \mathrm{p} \leq 0.005]$. Retinol /cholesterol ratio was decreased after HD session than before session [2.48 \pm 0.29 versus $2.35 \pm 0.25, \mathrm{p}<0.05]$.

After HD session, total cholesterol level was significantly decreased than beforeHD session $[161.6 \pm 10.37 \mathrm{mg} / \mathrm{dl}$ versus $201.54 \pm 13.77, \mathrm{p} \leq 0.002]$.

While, there was no significant difference in plasma retinol level, alpha tocopherol cholesterol ratio and TG level before and after HD session.

Table (1): Base line data of hemodialytic patients :-

\begin{tabular}{|c|c|}
\hline Age $($ mean \pm SE) & $49.5 \pm 11.3$ years \\
Sex : Males & $24(60 \%)$ \\
Females & $16(40 \%)$ \\
Dialysis time ( hours/session ) & 6 hours \\
Duration of dialysis(years \pm SE) & $4.5 \pm 2.4$ \\
Kt/v (mean \pm SD) & $1.12 \pm 0.23$ \\
& \\
\hline
\end{tabular}

Table (2): Plasma retinol, alpha-tocopherol, Lipid pattern and Their ratios among control and hemodialytic groups

\begin{tabular}{|c|c|c|}
\hline \multirow[t]{2}{*}{ Parameters } & $\begin{array}{c}\text { Control group } \\
(n=28)\end{array}$ & $\begin{array}{c}\text { Hemodialytic patients } \\
(\mathrm{n}=40)\end{array}$ \\
\hline & Mean \pm SE & Mean $\pm \mathrm{SE}$ \\
\hline Retinol (ug/dl) & $61.14 \pm 3.48$ & $465.27 \pm 26.72^{*}$ \\
\hline $\begin{array}{c}\text { Retinol/ } \\
\text { cholesterol ratio }\end{array}$ & $0.3966 \pm 0.02$ & $2.65 \pm 0.19 *$ \\
\hline $\begin{array}{c}\text { alpha-tocopherol } \\
\text { (ug/dl) }\end{array}$ & $891.24 \pm 36.21$ & $1323.04 \pm 150.32 *$ \\
\hline $\begin{array}{l}\text { alpha-tocopherol } \\
\text { /cholesterol ratio }\end{array}$ & $5.800 \pm 0.266$ & $6.62 \pm 0.55$ \\
\hline $\begin{array}{c}\text { Triglycerides } \\
(\mathrm{mg} / \mathrm{dl})\end{array}$ & $105.58 \pm 9.30$ & $187.56 \pm 23.25 *$ \\
\hline $\begin{array}{c}\text { Total cholesterol } \\
(\mathrm{mg} / \mathrm{dl})\end{array}$ & $166.63 \pm 6.71$ & $204.98 \pm 13.02 *$ \\
\hline
\end{tabular}

* $\mathbf{P}<\mathbf{0 . 0 5}=$ significant 
Table (3): Effect of hemodialysis on plama level of retinol, alpha-tocopherol, lipid pattern and their ratio for the subgroup $(n=13)$

\begin{tabular}{|c|c|c|}
\hline \multirow[t]{2}{*}{ Parameters } & Predialysis level & Postdialysis level \\
\hline & Mean \pm SE & Mean \pm SE \\
\hline Retinol (ug/dl) & $443.7 \pm 32.09$ & $430.8 \pm 33.16$ \\
\hline $\begin{array}{c}\text { Retinol / cholesterol } \\
\text { ratio }\end{array}$ & $2.35 \pm 0.25$ & $2.48 \pm 0.29 *$ \\
\hline $\begin{array}{c}\text { alpha-tocopherol } \\
\text { (ug/dl) }\end{array}$ & $1348.12 \pm 243.08$ & $1284.23 \pm 245.18 *$ \\
\hline $\begin{array}{l}\text { alpha-tocopherol } \\
\text { /cholesterol ratio }\end{array}$ & $6.25 \pm 0.64$ & $7.69 \pm 1.11$ \\
\hline Triglycerides (mg/dl) & $151.53 \pm 36.00$ & $187.35 \pm 13.77$ \\
\hline $\begin{array}{c}\text { Total cholesterol } \\
(\mathrm{mg} / \mathrm{dl})\end{array}$ & $201.54 \pm 13.77$ & $161.60 \pm 10.37^{*}$ \\
\hline
\end{tabular}

* $\mathbf{P}<\mathbf{0 . 0 5}=$ significant

\section{Discussion}

In previous surveys (Yatzidis et al., 1975 ; Werb et al.,1979 ; casey et al., 1981 ; Farrington et al., 1981 ; Gleghorn et al., 1986), although serum vitamin A level was elevated ( > 2SD) in patients with renal failure, clinical symptoms of hypervitaminosis A were not mentioned .Our results presented dramatic elevation of plasma retinol level in HD patients compared to healthy persons. However, we didn't check clinical manifestations of hypervitaminosis A. Failure of the kidney to metabolize retinol to retinoic acid may cause diminished excretion via bile and urine, thus leading to accumulation of retinol in chronic renal failure (CRF) (Ellis, et al. 1980). The elevation of serum vitamin A in renal failure patients has also been thought to be related to a defect in RBP catabolism by the diseased kidney (Chazot and Kopple, 2004). As RBP to retinol ratio is approximately $1: 1$, in renal failure patients the RBP values increase over normal and is often in excess of that seen for vitamin A. This may explain the lack of reported clinical symptomatology in renal failure patients, because toxicity may be caused by retinol and /or it's metabolites non specifically bound to plasma lipoproteins rather than to RBP (Gleghorn et al.,1986). The lipid status may influence vitamin A level in patients undergoing chronic dialysis. A positive correlation between plasma vitamin A levels and both serum total cholesterol and triglycerides has been observed in 72 patients undergoing maintenance hemodialysis (MHD), (Werb et al.,1979 and Smith et al.,1992). Even, individuals without renal failure and with hypertriglyceridemia were reported to be at increased risk of vitamin A toxicity because of increased bioavailability of retinyl esters from lipoproteins (Ellis et al.,1980). Because hyper-triglyceridemia occurs commonly in patients with renal failure, it is possible that those individuals also, may be at increased risk for vitamin A toxicity (Chazot and Kopple ,2004) . In this study, total cholesterol and triglycerides were significantly elevated in HD patients than in healthy individuals adding to the increased risk for vitamin A toxicity in these patients.

Among HD patients, the major cause of death is cardiovascular disease, which accounts for about $50 \%$ of the mortality in those patients (Rock et al., 1997). Vitamin $\mathrm{E}$ is the main antioxidant in biologic membranes, protecting phospholipids 
membranes from oxidative stress (Farrell and Roberts, 1993). Vitamin E is also, an antiatherogenic agent. Rimm et al., (1993) and Stampfer et al., (1993), studies have found a reduced risk of coronary heart disease in individuals with higher intake of vitamin $\mathrm{E}$. The mechanism of this protective effect is considered to be decreased oxidation of low density lipoprotein (LDL) cholesterol- a key step in the pathogenesis of the fatty streak, the first step in the development of the atheromatous plaque ( Chazot and Kopple, 2004) .

In this study, alpha-tocopherol level was significantly higher in patients receiving chronic HD therapy than control persons. The same results have been reported in previous studies(Mydlik et al.,1991,Fydryk et al.,1998).Other studies demonstrated no significant difference in alpha tocopherol level between HD patients and healthy control (Warwick et al., 2000 ). While another studies reported decreased alpha-tocopherol level in HD patients ( Rajbala et al., 1997 and Kinra et al., 2000 ) .

The oxidative stress associated with uremia is exacerbated by HD, since inflammatory cells (neutrophils, and monocytes) activated by contact with the dialysis membranes, release large amounts of reactive oxygen species (ROS) (Usberti et al., 2002). The deleterious effects of ROS on carbohydrates, lipids and proteins have a pathological role in many inflammatory diseases, most of which are frequent in HD patients (Galli et al., 1999a\&b).

Although some studies (De Bevere et al., 1982; Cristol et al., 1997 and De Cavanagh et al., 1999) found no difference in plasma vitamin $\mathrm{E}$ concentrations between predialysis and post dialysis samples. In this study, the HD procedure that exacerbates oxidative stress had significant effect on plasma alpha-tocopherol level. As, its level was significantly decreased after hemodialysis procedure. This may be due to increased consumption of alpha- tocopherol due to oxidative stress.

In contrast, the HD procedure had no significant effect on plasma retinol level. As it is a lipid soluble compound, so significant dialytic clearance of plasma retinol is not expected .

In conclusion, further studies are needed to answer, if hemodialytic patients are at risk for symptomatic vitamin A toxicity? The commertially available multivitamins preparations containing vitamin A may be hazardous for hemodialytic patients. Also, even with normal or low plasma vitamin $\mathrm{E}$, it may be needed as an antioxidant accessory therapy in hemodialytic patients.

\section{References}

1. Afifi Adel. Egyptian registry in: Proceedings of the Egyptian congress of nephrology 2003.

2. Allain CC, Poon LS, Chan CSG, et al. Enzymatic determination of total serum cholesterol. Clin Chem 1974 ; 20: 470-475.

3. Armitage $\mathbf{P}$, Statistical methods in medical research, Blackwell Scientific Publications 1971 , London .

4. Bieri JG, Tolliver TJ,and Catignani $G L$. Simultaneous determination of retinol and alpha-tocopherol in plasma or red cells by high pressure liquid chromatography. Am J Clin Nutr 1979; 32: 2143-49.

5. Casey CE, Moser MC, Hambidge M, et al. Zinc, copper and vitamin A in pediatric dialysis. J Pediatr 1981; 98:434-5.

6. Chazot $\mathbf{C}$ and Kopple $\mathbf{J}$ D. Vitamin metabolism and requirements in renal disease and renal failure . In : Kopple $\mathrm{J}$ $\mathrm{D}$, and Massry $\mathrm{S} G$,eds. Nutritional management of renal disease $.1^{\text {st }}$ ed. Lippincott Williams \& Wilkins : Awolter Kluwer company, Philadelphia New York, 1997 : 415-428.

7. Chazot $\mathbf{C}$ and Kopple J D. Vitamin metabolism and requirements in renal disease and renal failure. In : Kopple $\mathbf{J}$ $\mathrm{D}$, and Massry S G ,eds. Nutritional management of renal disease $.2^{\text {nd }}$ ed. Lippincott Williams \& Wilkins : Awolter Kluwer company, Philadelphia New York, $2004: 315-323$.

8. Cristol J P, Bosc J Y, Badiou S, et al. Erythropoietin and oxidative stress in hemodialysis : beneficial effects of vitamin E supplementation . Nephrol Dial Transplant 1997 ; 12: 2312-2317. 
9. De Bevere VO, Nelis HJ, De Leenheer AP et al. Vitamin E levels in hemodialysis patients .JAMA $1982 ; 247: 2371$.

10. De Cavanagh EM, Ferder L, Carrasquedo F,et al. Higher level of antioxidant defenses in enalapril-treated versus non-enalapril- treated hemodialysis patients .Am J Kidney Dis 1999 ; 34: 445455.

11. Ellis S, De Palma J, Cheng A,et al. Vitamin A supplements in hemodialysis patients . Nephron 1980; 26: 215-218.

12. Farrell $P$ and Roberts R. Vitamin E. In: Modern nutrition in health and disease. Shills M, Olson J, Shike M, eds. Philadelphia: Lea \& Febiger, 1993 : 326341.

13. Farrington K, Miller $\mathbf{P}$, Varghese $\mathbf{Z}$,et al. Vitamin A toxicity and hypercalcemia in chronic renal failure. $\mathrm{Br}$ Med J 1981 ; 282:1999-2002.

14. Fydryk J, Jacobson E, Kurzawska O,et al. Antioxidant status of children with steroid-sensitive nephrotic syndrom. Pediatr Nephrol 1998; 12: 751-754.

15. Galli F, Canestrari F, Bellomo G. Pathophysiology of the oxidative stress and its implication in uremia and dialysis. In Ronco, LaGerea G,eds. Vitamin $\mathrm{E}$ - Bounded membrane. A further step in dialysis optimization . Contrib Nephrol 1999a; 172: 1-31.

16. Galli F, Canestrari F, Buoncristiani U. Biological effects of oxidative stress in hemodialysis : the possible roles of vitamin E .Blood Purif 1999 b ; 17: 79- 94.

17. Gleghorn EE, Eisenberg LD, Hack Sh, et al. Observations of vitamin A toxicity in three patients with renal failure receiving parenteral alimentation. Am J Clin Nutr 1986 ; 44 july : 107-112.

18. Jacobson HR, Striker GE, Klahr S. The principles and practices of nephrology. $2^{\text {nd }}$ ed Mosby Comp. Baltimore, Tokyo, Toronto 1995 : 107-130.

19. Kinra S, Rath B, Kabi BC. Indirect quantification of lipid peroxidation in steroid responsive nephritic syndrome. Arch Dis Child 2000; 82: 76-78.

20. Mydlik M, Derzsiova K, Bratova M, et al. Serum vitamin A, retinyl esters and vitamin $\mathrm{E}$ in nephrotic syndrom. Int Urol Nephrol 1991; 23: 399-405.

21. National Kidney Foundation, Dialysis Outcome and Quality Initiative (DOQI) 2002. Guideline adequacy 6-12 .
22. Ongajooth L, Ongajyooth S, Likidlilid A, et al. Role of lipid peroxidation, trace elements and antioxidant enzymes in chronic renal disease patients . J Med Assoc Thai 1996 ; 79: 791-800.

23. Pastor MC, Sierra C, Bonal J, et al. Serum and erythrocyte tocopherol in uremic patients : effect of hemodialysis versus peritoneal dialysis. Am J Nephrol 1993 ; 13: 238-243.

24. Rajbala A,Sane AS, Zope J, et al. Oxidative stress status in children with nephrotic syndrome. Panminerva Med 1997; 39: 165-168.

25. Rimm EB, Stampfer MJ, Ascherio A, et al. Vitamin E consumption and the risk of coronary heart disease in men. N Engl J Med 1993 ; 328:1450-1456.

26. Rock CL, Jahnke MG, Gorenflo DW, et al. Racial group differences in plasma concentrations of antioxidant vitamins and carotinoids in hemodialysis patients . Am J Clin Nutr 1997; 65: 844 -50.

27. Smith DK, Greene JM, Leonard SB,et al. Vitamin A in hypercholesterolemia. Am J Med Sci 1992 ; 304: 20-24.

28. Stampfer MJ, Hennekens CH, Manson JE, et al. Vitamin E consumption and the risk of coronary disease in women . N Engl J Med 1993 ; 328: 1444-1449.

29. Usberti M, Geradi GM, Micheli AM, et al. Effect of a vitamin E- bounded membrane and of glutathione on anemia and erythropoietin requirements in hemodialysis patients .J Nephrol 2002 ; 15: 558564.

30. Wahlefeld AW. Triglycerides determination after enzymatic analysis. (Bergmeyer HV,ed) 1974, p 1831-1835. Academic press, New York and London.

31. Warwick GL, Waller H, ferns GA. Antioxidant vitamin concentration and LDL oxidant in nephritic syndrome. Ann Clin Biochem 2000; 34: 488-491.

32. Werb R, Clark WF, Lindsay RM et al. Serum vitamin A levels and associated abnormalities in patients on regular dialysis treatment. Clin Nephrol 1979; 12:63-8.

33. Yatzidis H,Digenis $\mathbf{P}$, Fountas $\mathbf{P}$. Hypervitaminosis A accompanying advanced chronic renal failure. Br Med J 1975 ; 3:352-4. 


\section{مستوى الرتينول والالفا - توكوفيرول فى مرضى الغسيل الكلوى (الدموى)}

عواطف محمد عبد المقصود1, أسماء محمود عبد الله ، وليد مسعود², مرفت أحمد اسماعيل1 1 أل (1) قسم التغذية الاكلينيكية - المعهد القومى للتعذية

(2) قسم الكلى - مستتفى أحمد ماهر التعليمى الاهئ

أجريت هذه الدر اسة لقياس مستوى الرتينول و الالفا توكوفيرول فى مرضسى الغسيل

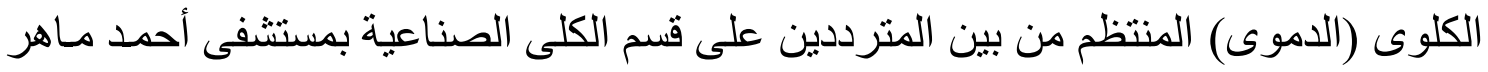

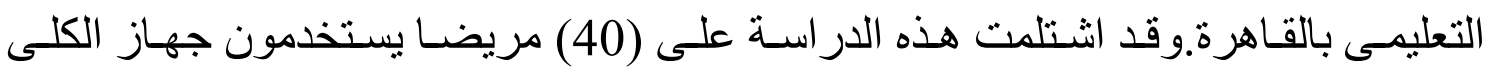

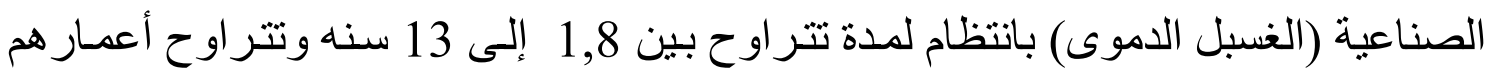

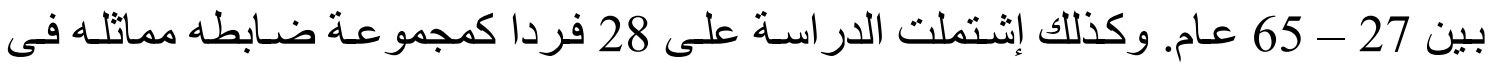

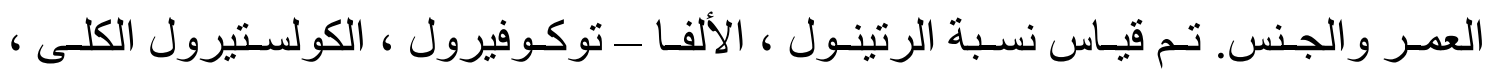

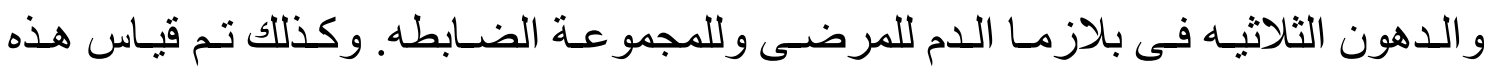
المؤشر ات فى 13 من المرضى قبل وبعد جلسه الغسيل الكلوى (الدموى).

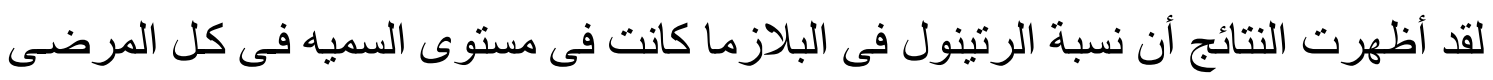

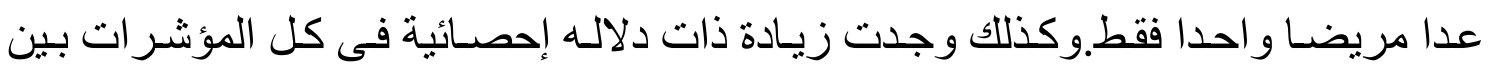

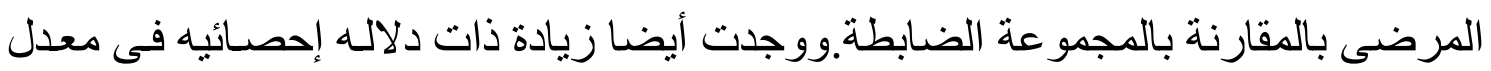

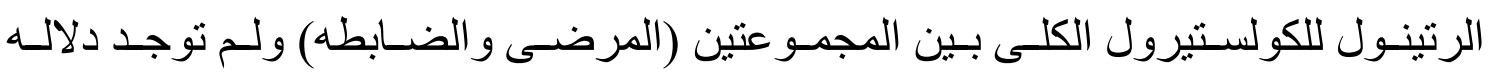

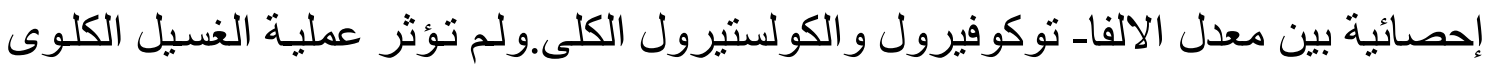

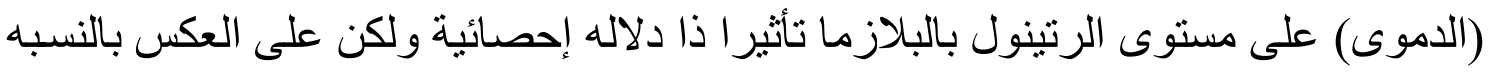
للألفا - توكوفيرول فقد حدث نقص فى مستو اه بالبلازما بعد عملية الغسيل الكلوى (الدموى) وكان النقص ذا دلاله إحصائية. نستخلص من هذه الدر اسه أننا نحتاج إلى دراسات ألى أخرى لتحديد ما إذا كان مرضسى الغسيل

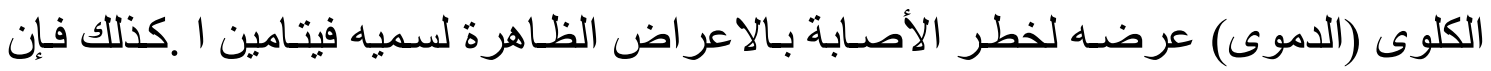

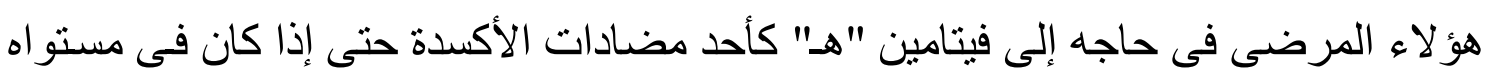

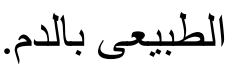

